\title{
GMR
}

\section{Identification of trends in scientific publications related to genetic polymorphisms in gestational diabetes mellitus}

\author{
J.S. Gomes ${ }^{1}$, L.B. Minasi ${ }^{2}$, A.D. da Cruz $^{2}$ and F.M. Rodrigues ${ }^{1,2}$ \\ ${ }^{1}$ Ciências Biológicas,Universidade Estadual de Goiás, Anápolis, GO, Brasil \\ ${ }^{2}$ Programa de Pós-Graduação em Genética, \\ Pontifícia Universidade Católica de Goiás, Goiânia, GO, Brasil \\ Corresponding author: F.M. Rodrigues \\ E-mail: rflamelo@gmail.com \\ Genet. Mol. Res. 15 (2): gmr.15027672 \\ Received September 17, 2015 \\ Accepted December 7, 2015 \\ Published May 6, 2016 \\ DOI http://dx.doi.org/10.4238/gmr.15027672
}

\begin{abstract}
Gestational diabetes is a genetic multifactorial systemic disease that has been extensively studied. Consequently, there is a large volume of scientific literature pertaining to genes associated with gestational diabetes. The aim of this study was to characterize the main trends in scientific publications focusing on the associations between genetic polymorphisms and gestational diabetes mellitus (GDM). The related articles were extracted from Scopus using the key words "genetic polymorphism" and "gestational diabetes mellitus"; the collected data focused on various fields (medical, biochemical, etc.) and included papers published within December 2013. One hundred and eighty-three relevant articles published between 1987 and 2013 were identified; we observed a significantly increasing trend in the number of publications pertaining to GDM. A majority of the articles focused on the medical (59.9\%), biochemical, and genetics and molecular biological (29.6\%) aspects of the disease. The genes coding for transcription factor 7-like 2 and glucokinase (TCF7L2, 29\% and GCK, 28\%) were predominantly studied and reported. This study helped quantify the growth in research
\end{abstract}


pertaining to GDM; researchers from the USA have published a majority of the publications related to GDM. Several candidate genes have been linked to diabetes; however, the specific gene locus responsible for GDM has not yet been identified. The results of this study could help determine the orientation of future research on genetic factors associated with GDM.

Key words: Gestational diabetes mellitus; Polymorphism; Scientific production

\section{INTRODUCTION}

Diabetes mellitus (DM) is a group of metabolic diseases characterized by hyperglycemia resulting from defects in insulin secretion and/or insulin action. Various microand macrovascular alterations are among the long-term complications of DM (ADA, 2012). Recent studies have attempted to elucidate the genetic basis of this disorder; in most cases, DM is believed to be multifactorial, caused by both genetic and environmental factors (Hirata and Hirata, 2006). Changing eating habits and a sedentary lifestyle, combined with genetic determinants, play important roles in the pathogenesis of this disease (Bougnères, 2002; Veloso, 2005).

Diabetes mellitus is a disease with a high degree of prevalence worldwide, affecting over 150 million people (Takaku et al., 2006). In Brazil, 7.6\% of the population aged 3069 years are believed to have DM; approximately $50 \%$ of these people are unaware of their diagnosis, while $24 \%$ do not undergo any kind of treatment. Chronic complications are the major factor influencing morbidity and mortality in diabetic patients (Gross and Nehme, 1999).

The vast majority of diabetic patients are classified into one of two broad categories: type 1 diabetes mellitus (caused by an absolute deficiency of insulin) and type 2 diabetes mellitus (characterized by the presence of insulin resistance, with an inadequate compensatory increase in insulin secretion). In addition, women who develop diabetes during their pregnancy are diagnosed with gestational diabetes. Additionally, there are some uncommon and diverse types of diabetes, such as maturity onset diabetes of the young (MODY) and mitochondrial diabetes (Gross et al., 2002; Thomas and Philipson, 2015).

Gestational diabetes mellitus (GDM) is identified by glucose intolerance with onset or first recognition during pregnancy; this occurs when unrecognized glucose intolerance is antedated or begins concomitantly with pregnancy (Basso et al., 2007). The pathology of GDM includes an increase in counter regulatory hormones of insulin, physiological stress caused by pregnancy, and genetic or environmental factors. This occurs in $2-3 \%$ of pregnant women; in most of these cases, there is a reversal of diabetic state to normal glucose tolerance after pregnancy. However, $17-63 \%$ of the resulting infants are at a high risk of developing type 2 diabetes mellitus 5-16 years after childbirth (Hanna and Peters, 2002).

GDM prevalence occurs at a range of $1-14 \%$ of pregnant women, depending on the population studied. GDM is the major cause of diabetes-related pregnancy complications (nearly 90\%), and is associated with an increase in perinatal morbidity and mortality (Coustan, 1995; Gilmartin et al., 2008). In Brazil, GDM occurs at a frequency of 3-13\% among all pregnancies (SBD, 2009). The major hormone related to insulin resistance during pregnancy 
is lactogen placental hormone; other hyperglycemic hormones, including cortisol, estrogen, progesterone, and prolactin are also involved (ADA, 2005).

According to Kwak et al. (2012), knowledge regarding the genetic risk loci for GDMremains rather limited. Among the known type 2 diabetes-related genes, those that are thought to modulate pancreatic $\beta$-cell function were preferentially associated with GDM (CDKAL1, MT$N R 1 \mathrm{~B}, I G F 2 B P 2, C D K N 2 A / 2 B, S L C 30 A 8, I D E, K C N Q 1$, and CENTD2). These findings support the previous theory that the use of defective pancreatic $\beta$-cell compensation to overcome increased insulin resistance during pregnancy might be the core pathophysiology of GDM.

The recent advances in research and scientific methods, and their related literature, have led to a corresponding increase in the use of scientometric methods (Mugnaini et al., 2004; Vanti, 2002). These quantitative methods are used to study scientific activities, including the production or communication of these activities (Bufrem and Prates, 2005). The analysis of scientific production in a given area generates instruments to guide policies and programs for investments in technology, science, and health (Holbrook, 1992). The aim of this study was to characterize the tendency of scientific production to focus on genetic polymorphism in gestational diabetes mellitus, using scientometric analysis.

\section{MATERIAL AND METHODS}

This study is a quantitative description of scientific production using related scientific articles from Scopus. Scopus is the largest abstract and citation database of peer-reviewed literature belonging to Elsevier. It includes several search tools to track, analyze, and visualize articles providing sufficient information to researchers to base their projects on, be it basic, applied, or technical research and innovation (SCOPUS, 2012).

Scientific articles were extracted from SCOPUS between October and November 2013 using the key words "genetic polymorphism" and "gestational diabetes". The options "all fields" and "all publications to date" were applied to the specialized areas "life sciences", "health science", and "physical sciences". Asterisks were used to extract articles using derivations of the keywords. The abstracts of all selected articles were thoroughly scrutinized, and some pertinent information, such as the year of publication, specialized subject area of the journal, journal name, the country of nationality of the first author, studied genes, and significant correlation between gene polymorphism and GDM, were recorded.

The obtained data were analyzed using the Spearman correlation test, and the significance level was set at $\mathrm{P} \leq 0.05$. The data were analyzed using Bioestat 5.0 (Ayres et al., 2007).

\section{RESULTS AND DISCUSSION}

We identified 183 scientific articles published between the years 1987 and 2013. According to Figure 1, the number of publications increased over time $(\mathrm{P}<0.0001)$, with the maximum number of 22 articles being published in 2012. The progressive growth of scientific knowledge was positively related to the increase in number of articles, used as a measure to quantify the progress and development of science and to assess the impact of productivity and research activity (Verbeek et al., 2002). The increase in number of publications could be attributed to the availability of publications, research, and projects on the Internet (Hey et al., 2009). 


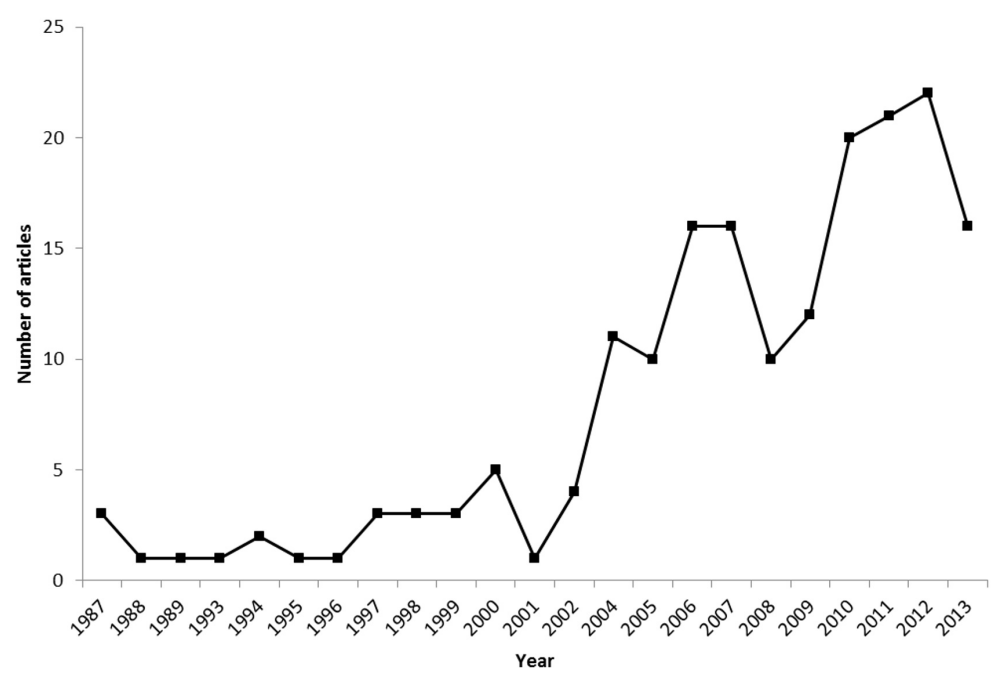

Figure 1. Number of articles published during the period 1987-2013.

Medicine is the major subject area incorporated in a majority of the articles regarding GDM, corresponding to 59.9\%; however, this field only focuses on the pathology, diagnosis, and treatment of GDM. The biochemistry, genetics, and molecular biology fields $(29.6 \%)$ address the pathological, biochemical, and genetic causes of disease. The biological and agricultural sciences account for approximately $2.9 \%$ and $<2 \%$, and are therefore minor fields of study addressing the topic of interest (Figure 2). The approach with which GDM is handled in these fields is a reflection of the interaction between researchers from different areas of expertise, providing a broad view of its structure and dynamics (Newman, 2003). Interactions between researchers from different fields result in the effective evaluation and promotion of science and technology, since it focuses on producing a large number of publications of high quality (Balancieri et al., 2005; Kim, 2006).

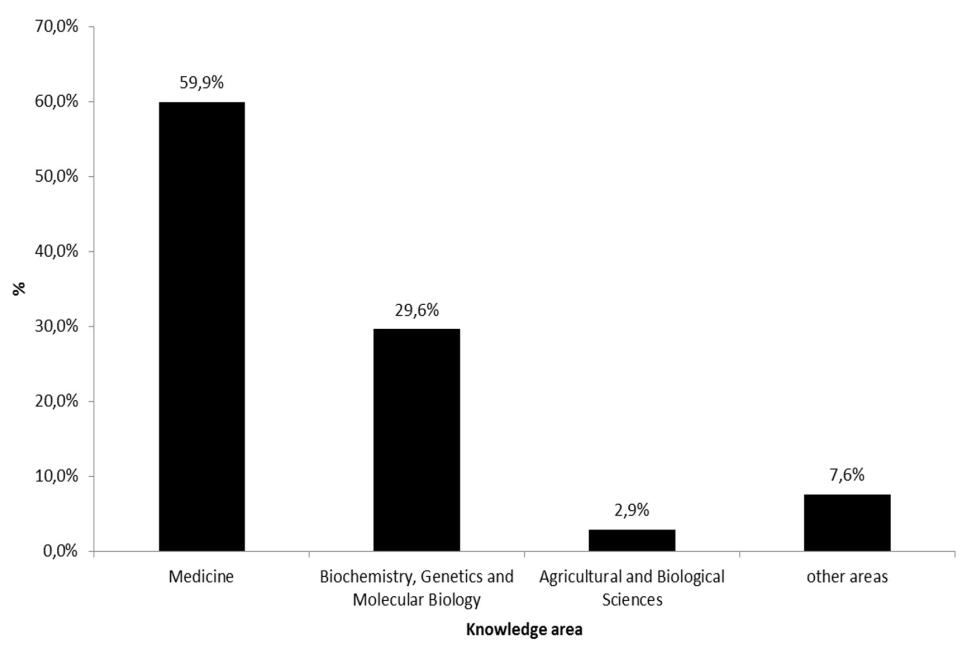

Figure 2. Distribution of the percentage of articles within the different areas of knowledge for gestational diabetes mellitus. 
So far, the journal Diabetes has published the highest number of articles (21) focusing on genetic polymorphisms in GDM, followed by Diabetes Research and Clinical Practice, Diabetologia, and the Journal of Clinical Endocrinology and Metabolism (8 each; Figure 3). According to Macias-Chapula (1998), science should be recognized as a broad social system with a function of disseminating knowledge, giving credit and recognition to those whose research contributes to the development of ideas in different fields of knowledge.

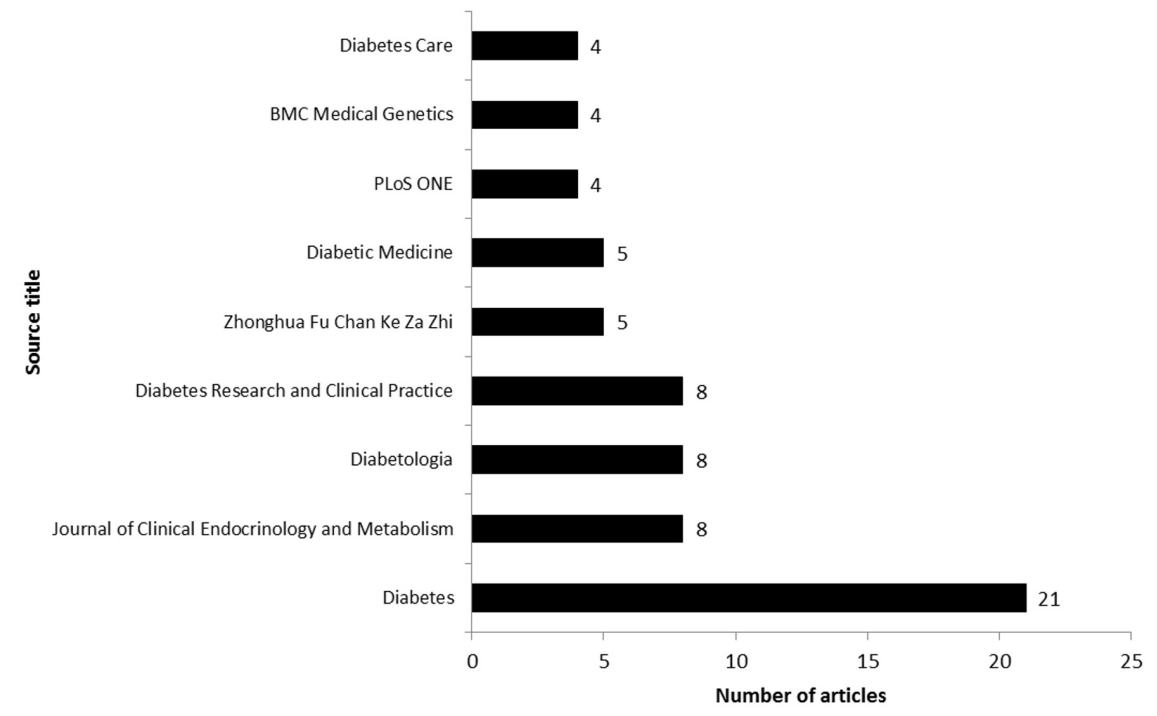

Figure 3. Journals that most published articles involving gestational diabetes mellitus.

Researchers from the USA published the highest number of articles $(43 ; 19 \%)$ from among the 39 countries with publications pertaining to the subject of interest, followed by England with 30 articles (13\%; Table 1). The large number of publications from researchers from the USA reflects the country's attitude, infrastructure, and investment into scientific research. Currently, scientific activity is highly concentrated in industrialized countries, with developing countries facing difficulties in conducting work in specific areas, because of the need for advanced equipment (Carneiro et al., 2008). Brazil, with 5 published articles, was at position 15 compared to other countries; this is an optimistic trend, as most countries have no more than 1, 2, or 3 articles pertaining to genetic polymorphisms in GDM. The Brazilian scientific community has grown considerably over the last two decades, which is reflected in the number of publications; however, it remains far behind the professed first-world countries with regard to knowledge pertaining to GDM, as well as other fields of knowledge (Leta and Chaimovich, 2002).

Twenty-five of the 183 analyzed articles pertained to aspects related to the pathology, epidemiology, diagnosis, treatment, and psychology of GDM; the remaining (158) reported on genetic polymorphisms related to GDM. A majority of these $(141 / 158 ; 89 \%)$ identified one or more genes that were significantly associated to GDM, while the remaining $(17 / 15 ; 11 \%)$ reported no significant associations between genetic polymorphism and the pathology of GDM (Figure 4). The large number of articles describing genes related to GDM reflects the extensive 
research conducted to promote and broaden the knowledge pertaining to the pathophysiology of diabetes over the past few decades, wherein a number of genetic polymorphisms associated with different types of diabetes, including GDM, have been described (Tang et al., 2012).

Table 1. Number $(\mathrm{N})$ and percentage $(\%)$ of countries with ten or more publications pertaining to gestational diabetes mellitus.

\begin{tabular}{l|c|c}
\hline Country & $\mathrm{N}$ & $\%$ \\
\hline The United States of America & 43 & 19 \\
\hline The United Kingdom & 30 & 13 \\
\hline South Korea & 12 & 5 \\
\hline China & 11 & 5 \\
\hline France & 11 & 4 \\
\hline Finland & 10 & 48 \\
\hline Others & 110 & 100 \\
\hline Total & 227 & 5 \\
\hline
\end{tabular}

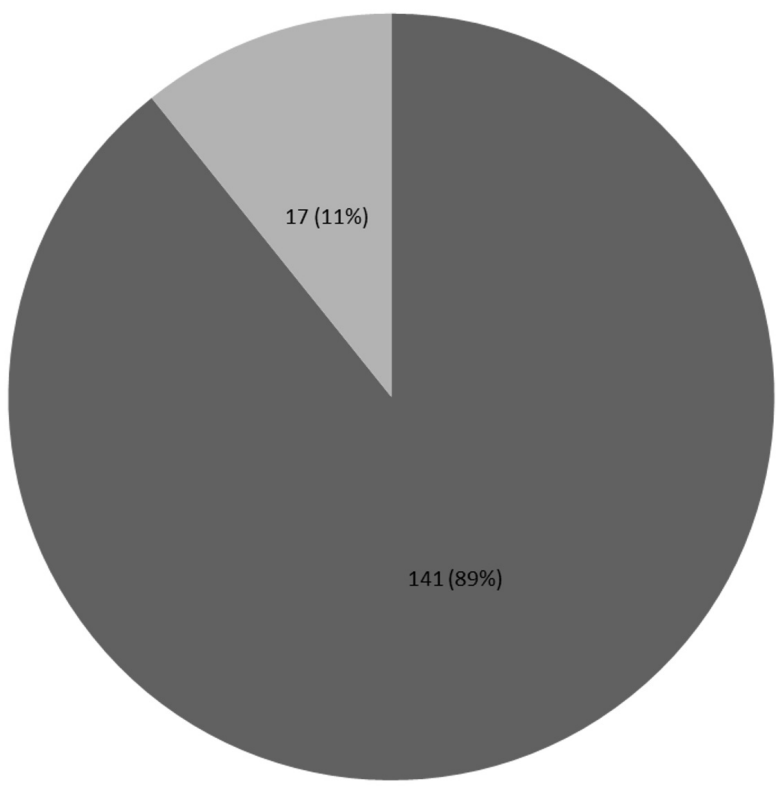

- Significant association

No significant association

Figure 4. Frequency of articles that presented significant association with gestational diabetes mellitus and genetic polymorphisms.

The 141 scientific articles reporting a significant correlation between the expression of certain genes and GDM studied a total of 90 different genes (Table 2). The transcription factor 7-like 2 (TCF7L2) gene has been studied the most, with 17 articles (29\%) analyzing this gene. This gene was found to increase the risk to type $2 \mathrm{DM}$ by 1.7 times; recent studies have also suggested that this gene is involved in the secretion of insulin, as its suppression promotes a reduction in hormone secretion (Shu et al., 2008). TCF7L2 gene polymorphisms were also strongly associated with GDM in a recent systematic review published by Zhang et al. (2013). 
Table 2. Genes associated with gestational diabetes mellitus analyzed in two or more studies.

\begin{tabular}{l|c|c}
\hline Genes studied & $\mathrm{N}$ & $\%$ \\
\hline$T C F 7 L 2$ & 17 & 29 \\
\hline GCK & 16 & 28 \\
\hline KCNJII/CDKALI/MTNRIB & 7 & 12 \\
\hline$P P A R / A D R B 3 / A C E$ & 6 & 10 \\
\hline$I F G 2 B P 2 / K C N Q 1 / T N F-\alpha / P P A R G / S U R 1$ & 5 & 9 \\
\hline$I R S 1 / I F G-I$ & 4 & 7 \\
\hline$I F G 2 / P A I-I / H N F 1 A$ & 3 & 100 \\
\hline Total & 58 & \\
\hline
\end{tabular}

The glucokinase (GCK) gene, reported in 16 articles (28\%), is responsible for glucose metabolism, with mutations resulting in an impairment of glucose metabolism in beta cells, in turn down-regulating the expression of insulin and hepatic metabolism of glucose (Hirata and Hirata, 2006). A recent study in Scandinavian women showed that a polymorphism in the rs 1799884 locus of $G C K$ was associated with GDM (Shaat et al., 2006).

The KCNJ11, CDKAL1, and MTNR1B genes, coding for the potassium inwardly rectifying channel (subfamily J, member 11), kinase 1 cyclin dependent (rs7754840), and $1 \mathrm{~b}$ melatonin receptor (rs 10830963), were studied in seven articles each (12\%). Polymorphisms in the KCNJ11 gene were associated with high risk of DM2, resulting in hyperglycemia due to the improper response of the body to the insulin secreted by beta cells. Shaat and Groop (2007) analyzed the effect of polymorphisms in the genes coding for proteins involved in potassium channel mechanisms, and discovered that the polymorphism E23K in the KCNJ11 gene is a predictor of GDM in Scandinavian women.

The SNP rs5945326 in CDKAL1 was associated with DM2 in different populations (Scott et al., 2007). The strong genetic correlation between DM2 and GDM led to the evaluation of this polymorphism in gestational diabetes. Accordingly, Kwak et al. (2012) reported a correlation between this polymorphism and GDM in a Korean population; however, this must be validated in other populations.

A study pertaining to the functional interaction of the hormone melatonin via the MTNR1B receptor (coded by the MTNR1B gene) discovered that melatonin induces a decrease in the secretion of insulin by pancreatic beta cells; consequently, this hormone was associated with the pathogenesis of diabetes. Additionally, polymorphisms in the MTNR1B gene were associated with increased risk of DM2. Moreover, an association was observed between the rs 10830963 polymorphism and GDM in different populations; however, this must be further validated in other populations (Kim et al., 2011).

The PPAR and ADRB3 genes, coding for the proliferator-activated receptor peroxisome and b3-adrenergic receptor encoder, were analyzed in 6 articles (10\%). PPAR is a transcription factor belonging to a family of nuclear receptors that regulate glucose homeostasis, lipid metabolism, and inflammation (Tavares et al., 2007). A recent study of PPAR gene polymorphisms in 136 pregnant Korean women identified a positive correlation between the two (Chon et al., 2013). Another study associated polymorphisms in the ADRB3 gene with a predisposition to GDM (Shaat and Groop, 2007).

This analysis revealed that publications pertaining to GDM have increased gradually over the past 27 years. A majority of these articles primarily deal with the medical aspect of GDM; developed countries, such as the USA and UK, have performed considerable research on this subject, and the journal Diabetes, specializing in this field, has published the highest 
number of articles pertaining to GDM. A majority of studies have identified a significant association between genetic polymorphisms and GDM; in this regard, polymorphisms in the TCF $7 L 2$ gene have been extensively analyzed. The results of this study could contribute towards determining the orientation of future research pertaining to the genetic factors associated with GDM.

\section{Conflicts of interest}

The authors declare no conflict of interest.

\section{ACKNOWLEDGMENTS}

The authors would like to thank PIBIC/UEG for the study scholarship.

\section{REFERENCES}

American Diabetes Association (ADA) (2005). Diagnosis and classification of diabetes mellitus. Diabetes Care 28 (Suppl 1): S37-S42. http://dx.doi.org/10.2337/diacare.28.suppl_1.S37

American Diabetes Association ADA (2012). Diagnosis and classification of diabetes mellitus. Diabetes Care 35: 64-71.

Ayres M, Junior MA, Ayres DM, Antos AS, et al. (2007). BioEstat. Aplicações Estatísticas nas áreas das ciências biomédicas, Belém do Pará, Brasil.

Balancieri R, Bovo AB, Medina V, Pacheco R, et al. (2005). A análise de redes de colaboração científica sob as novas tecnologias de informação e comunicação: Um estudo na plataforma Lattes. Cienc. Inf. 34: 64-77. http://dx.doi. org $/ 10.1590 / \mathrm{S} 0100-19652005000100008$

Basso NAS, Costa RAA, Magalhães CG, Rudge MVC, et al. (2007). Insulinoterapia, controle glicêmico materno e prognóstico perinatal: diferença entre o diabetes gestacional e o clínico. Rev. Bras. Ginecol. Obstet. 29: 253-259.

Bougnères $P$ (2002). Genetics of obesity and type 2 diabetes: tracking pathogenic traits during the predisease period. Diabetes 51 (Suppl 3): S295-S303. http://dx.doi.org/10.2337/diabetes.51.2007.S295

Bufrem L and Prates Y (2005). O saber científico registrado em práticas de mensuração da informação. Cienc. Inf. 34: 9-25. http://dx.doi.org/10.1590/S0100-19652005000200002

Carneiro FM, Nabout JC and Bini LM (2008). Trends in the scientific literature on phytoplankton. Limnology 9: 153-158. http://dx.doi.org/10.1007/s10201-008-0242-8

Chon SJ, Kim SY, Cho NR, Min DL, et al. (2013). Association of variants in PPARg², IGF2BP2, and KCNQ1 with a susceptibility to gestational diabetes mellitus in a Korean population. Yonsei Med. J. 54: 352-357. http://dx.doi. org/10.3349/ymj.2013.54.2.352

Coustan DR (1995). Gestational diabetes. In: Diabetes in America (Harris MI, Ed.). Maryland, National Institute of Health, Bethesda, 703-716.

Gilmartin AB, Ural SH and Repke JT (2008). Gestational diabetes mellitus. Rev. Obstet. Gynecol. 1: 129-134.

Gross JL and Nehme M (1999). Detecção e tratamento das complicações crônicas do diabetes melito: consenso da Sociedade Brasileira de Diabetes e Conselho Brasileiro de Oftalmologia. Rev. Assoc. Med. Bras. 45: 279-284. http:// dx.doi.org/10.1590/S0104-42301999000300014

Gross JL, Silveiro SP, Camargo JL and Reichelt AJ (2002). Diabetes Melito: diagnóstico, classificação e avaliação do controle glicêmico. Arq. Bras. Endocrinol. Metabol. 46: 16-26. http://dx.doi.org/10.1590/S0004-27302002000100004

Hanna FW and Peters JR (2002). Screening for gestational diabetes; past, present and future. Diabet. Med. 19: 351-358. http://dx.doi.org/10.1046/j.1464-5491.2002.00684.x

Hey T, Tansley S and Tolle K (2009). The fourth paradigm: Data intensive scientific discovery. Redmond, WA. http:// research.microsoft.com/en-us/collaboration/fourthparadigm. Accessed July 21, 2014.

Hirata RDC and Hirata MH (2006). Farmacogenética do tratamento de diabete melito. In: Simpósio: Farmacogenética, Medicina, Ribeirão Preto. 39: 554-561.

Holbrook JAD (1992). Why measure science? Sci. Publ. Pol. 262-266.

Kim JY, Cheong HS, Park BL, Baik SH, et al. (2011). Melatonin receptor 1 B polymorphisms associated with the risk of gestational diabetes mellitus. BMC Med. Genet. 12: 82. http://dx.doi.org/10.1186/1471-2350-12-82 
Kim KW (2006). Measuring international research collaboration of peripheral countries: Taking the context into consideration. Scientometrics 66: 231-240. http://dx.doi.org/10.1007/s11192-006-0017-0

Kwak SH, Kim SH, Cho YM, Go MJ, et al. (2012). A genome-wide association study of gestational diabetes mellitus in Korean women. Diabetes 61: 531-541. http://dx.doi.org/10.2337/db11-1034

Leta J and Chaimovich W (2002). Recognition and international collaboration: The Brazilian case. Scientometrics 53: 325-335. http://dx.doi.org/10.1023/A:1014868928349

Macias-Chapula CA (1998). O papel da informetria e da cienciometria e sua perspectiva nacional e internacional. Cienc. Inf. 27: 134-140. http://dx.doi.org/10.1590/S0100-19651998000200005

Mugnaini R, Jannuzzi P and Quoniam L (2004). Indicadores bibliométricos da produção científica brasileira: uma análise a partir da base Pascal. Cienc. Inf. 33: 123-131. http://dx.doi.org/10.1590/S0100-19652004000200013

Newman MEJ (2003). The structure and function of complex networks. SIAM Rev. 45: 167-256. http://dx.doi.org/10.1137/ $\underline{\mathrm{S} 003614450342480}$

SBD (Sociedade Brasileira de Diabetes) (2009). Tratamento e acompanhamento do diabetes mellitus: diretrizes da SBD. $\mathrm{SBD}$, Rio de Janeiro.

SCOPUS (2012). Elsevier; 2012. http://www.scopus.com. Accessed August 6, 2012.

Scott LJ, Mohlke KL, Bonnycastle LL, Willer CJ, et al. (2007). A genome-wide association study of type 2 diabetes in Finns detects multiple susceptibility variants. Science 316: 1341-1345. http://dx.doi.org/10.1126/science.1142382

Shaat N and Groop L (2007). Genetics of gestational diabetes mellitus. Curr. Med. Chem. 14: 569-583. http://dx.doi. org/10.2174/092986707780059643

Shaat N, Karlsson E, Lernmark A, Ivarsson S, et al. (2006). Common variants in MODY genes increase the risk of gestational diabetes mellitus. Diabetologia 49: 1545-1551. http://dx.doi.org/10.1007/s00125-006-0258-8

Shu L, Sauter NS, Schulthess FT, Matveyenko AV, et al. (2008). Transcription factor 7-like 2 regulates $\beta$-cell survival and function in human pancreatic islets. Diabetes 57: 645-653. http://dx.doi.org/10.2337/db07-0847

Takaku M, Takeno MA, Rudge MVC and Damasceno DC (2006). Tipos de Diabete. Rev. Femina. 34.

Tang S, Peng W, Wang C, Tang H, et al.(2012). Association of the PTPN22 gene (+1858C/T, -1123G/C) polymorphisms with type 1 diabetes mellitus: a systematic review and meta-analysis. Diabetes Res. Clin. Pract. 97: 446-452. http:// dx.doi.org/10.1016/j.diabres.2012.04.011

Tavares V, Hirata MH and Hirata RDC (2007). Receptor ativado por proliferadores de peroxissoma gama (PPAR $\gamma$ ): estudo molecular na homeostase da glicose, metabolismo de lipídeos e abordagem terapêutica. Arq. Bras. Endocrinol. Metabol. 51: 4. http://dx.doi.org/10.1590/S0004-27302007000400005

Thomas CC and Philipson LH (2015). Update on diabetes classification. Med. Clin. North Am. 99: 1-16. http://dx.doi. org/10.1016/j.mcna.2014.08.015

Vanti NAP (2002). Da bibliometria à webometria: uma exploração conceitual dos mecanismos utilizados para medir o registro da informação e a difusão do conhecimento. Cienc. Inf. 3: 152-162.

VelosoLA (2005). Resistência hipotalâmica à insulina existe? Endocronol. Metabol. 49: 797.

Verbeek A, Debackere K, Luwel M and Zimmermann E (2002). Measuring progress and evolution in science and technology - I: The multiple uses of bibliometric indicators. Int. J. Manag. Rev. 4: 179-211. http://dx.doi.org/10.1111/14682370.00083

Zhang C, Bao W, Rong Y, Yang H, et al. (2013). Genetic variants and the risk of gestational diabetes mellitus: a systematic review. Hum. Reprod. Update 19: 376-390. http://dx.doi.org/10.1093/humupd/dmt013 